\title{
PEMANFAATAN LIMBAH BULU AYAM POTONG SEBAGAI PELET PAKAN LELE UNTUK MENEKAN BIAYA PRODUKSI BETERNAK LELE
}

\author{
Suwarto \\ Fakultas Pertanian, Universitas Sebelas Maret Surakarta \\ email: suwartouns @ gmail.com
}

\begin{abstract}
This IbM program in collaboration with two partners, namely: (1) Traders and Chicken butcher 'Narti Ayam, and (2) Catfish Livestock "Berlian Catfish". Partner (1) is located in Karangrejo, Ngringo village, Jaten, Karanganyar, with a distance of about $3 \mathrm{~km}$ from Faculty of Agriculture UNS. Business field developed by partners (1) is the business of slaughtering chicken pieces. Partners (2) located in the hamlet of Gunung Sari, Ngringo village, district. Cork, Kab. Karanganyar, Central Java with a distance of about $\pm 3.5 \mathrm{~km}$. Business fields developed by partners (2) are catfish farms. The location is very close to both partners, only about $0.5 \mathrm{~km}$. Consumer demand for chicken and catfish in Karanganyar and surrounding per day is very high, has not been able to be met by both the business partners. 1 business partners in the activities of this IbM facing major problems, namely the handling of waste chicken feathers with an average production capacity of \pm 300 head / day. Very high production speeds also produce very high feather waste, which is about $100 \mathrm{~kg}$ of waste per day (3 tons per month). This has the potential to pollute the environment in the form of a pungent odor and pollutant source for the water body. While the two business partners in the activities of this IbM facing major problems that must provide catfish feed cost of purchasing very high, reaching an average of $R p .1 .23$ million to Rp. 1,640,000 / week.IbM activity is trying to overcome the problems faced by business partners (1), by exploiting the potential of waste chicken feathers for the manufacture of catfish feed through manufacture pellets mixed with other materials that have a high nutritional value and seek to overcome the problems faced by business partners (2), by utilizing waste chicken feathers are made of pellets can reduce the production cost of raising catfish. The application of the proposed technology will produce an integrated business activities slaughter broilers - catfish farms without waste, making it environmentally friendly, and produce coherence between slaughter chicken and catfish breeding mutually beneficial.The results that have been achieved in service activities are: (1) assistance pellet making machine 1 unit with a capacity of $40 \mathrm{~kg} / \mathrm{h}$; (2) support a high-pressure cooker (pressure cooker) 1 unit with a capacity of $70 \mathrm{~kg}$; (3) assistance Removers Tools quill 1 unit; (4) Utilization of quail droppings, feathers and waste; (5) The practice of making pellets using quail dung mixed salted fish waste, and waste feathers. Help set of machine tools for the manufacture of catfish feed from raw materials to finished pellets help solve waste chicken feathers Chicken slaughtering Traders 'Narti Chicken' and can overcome the high cost of production in the Ranch Lele 'Diamond Catfish'.
\end{abstract}

Keywords: feather chicken, catfish feed pellets, production costs, raising catfish

\section{PENDAHULUAN}

Budidaya ikan lele dikembangkan pada 15 buah kolam, dan setiap kolam rata-rata berisi $2.000-2.500$ ekor lele. Pada saat panen lele baru dapat dilakukan setiap 1 minggu sekali, dengan rata-rata produksi per kolam sekitar $150-200 \mathrm{~kg}$, dengan rata-rata harga lele Rp. 12.000,- per kg. Kapasitas produksi lele saat ini juga belum mampu menyediakan permintaan lele yang tinggi untuk melayani konsumen di Karanganyar dan sekitarnya.
Sebanyak 12-16 ton ikan lele dikonsumsi oleh masyarakat Yogyakarta tiap hari. Hal ini dikarenakan banyaknya warung-warung pecel lele yang dibuka di kota pelajar ini setiap malam. (http://www.waspada.co.id)

Pemanfaatan limbah bulu ayam sebagai bahan pembuatan pelet, akan menghasilkan pakan lele yang tidak kalah mutunya dengan buatan pabrik. Pemanfaatan limbah bulu ayam untuk bahan pembuatan pelet merupakan wujud nyata dari penerapan peniadaan limbah 


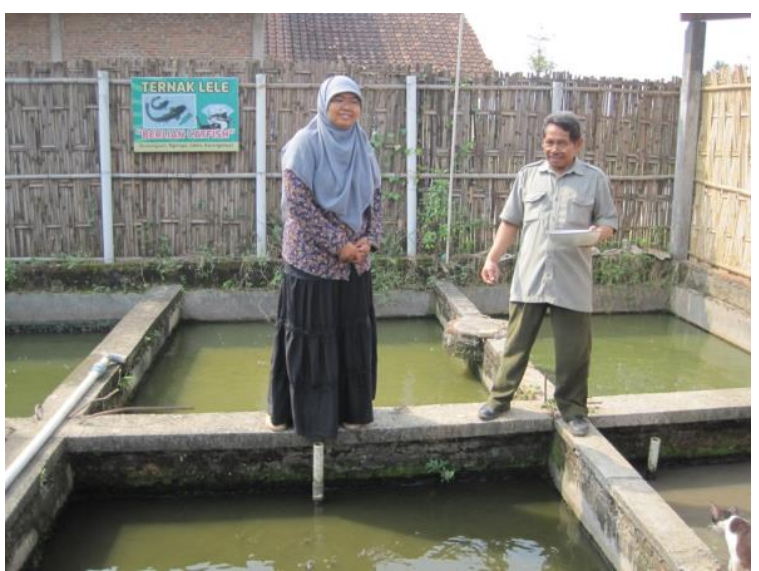

Mitra (1) Berlian Catfish

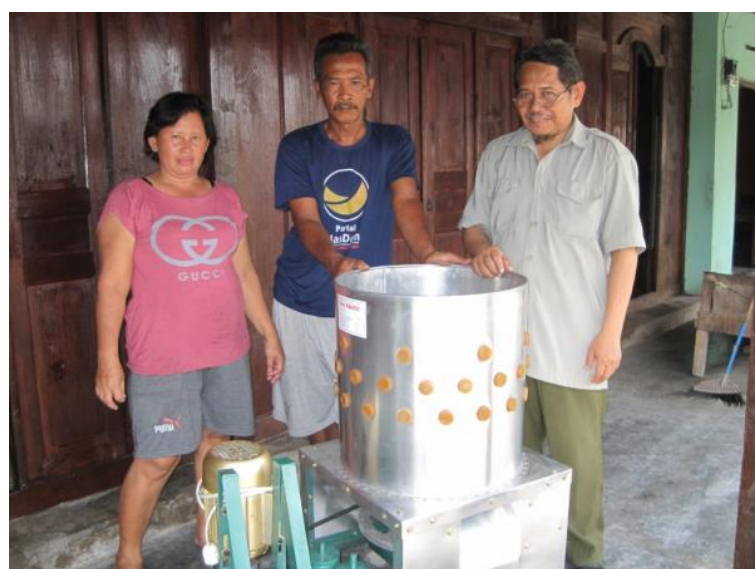

Mitra (2) Narti Ayam secara terpadu. Dengan demikian selain akan memberikan peningkatan penghasilan bagi peternak, maka juga akan meningkatkan kualitas produk lele organik, pengurangan biaya produksi, dan tidak mencemari lingkungan.

Program IbM ini bekerjasama dengan dua mitra, yaitu: (1) Pedagang Penyembelih Ayam 'Narti Ayam', dan (2) Peternakan Lele "Berlian Catfish". Mitra (1) berlokasi di dukuh Karangrejo, Desa Ngringo, Kec. Jaten, Kab. Karanganyar, dengan jarak tempuh sekitar 3 $\mathrm{km}$ dari Fak. Pertanian UNS. Bidang usaha yang dikembangkan oleh mitra (1) tersebut adalah usaha penyembelihan ayam potong. Mitra (2) berlokasi di dukuh Gunung Sari, Desa Ngringo, Kec. Jaten, Kab. Karanganyar, Jawa Tengah dengan jarak tempuh sekitar \pm $3,5 \mathrm{~km}$. Bidang usaha yang dikembangkan oleh mitra (2) tersebut adalah peternakan lele. Lokasi kedua mitra sangat berdekatan, hanya sekitar 0,5 km. Permintaan konsumen terhadap daging ayam dan ikan lele di Karanganyar dan sekitarnya per hari sangat tinggi, belum mampu dipenuhi oleh kedua mitra usaha tersebut.

Permasalahan Mitra 1 (Narti Ayam) dalam kegiatan IbM ini menghadapi permasalahan utama yaitu penanganan limbah bulu ayam dengan kapasitas produksi rata-rata \pm 300 ekor/hari. Kecepatan produksi yang sangat tinggi ini juga menghasilkan limbah bulu yang sangat tinggi, yaitu sekitar $100 \mathrm{~kg}$ limbah per hari (3 ton per bulan). Hal ini berpotensi mencemari lingkungan berupa bau yang menyengat dan sumber pencemar bagi badan perairan.

Permasalahan Mitra 2 (Berlian Catfish) dalam kegiatan $\mathrm{IbM}$ ini menghadapi permasalahan utama yaitu harus menyediakan biaya pembelian pakan lele yang sangat tinggi, rata-rata mencapai Rp. 1.230.000 sampai Rp. 1.640.000/minggu.

Solusi yang ditawarkan untuk mengatasi permasalahan utama yang dihadapi mitra (1) adalah teknologi penanganan limbah bulu ayam untuk pembuatan pelet. Dalam pelet, tepung bulu ayam dicampur dengan bahan lain yang berupa usus ayam yang tidak termanfaatkan dan limbah lain yang tidak termanfaatkan yang bisa digunakan sebagai campuran pakan lele yang memiliki nilai gizi tinggi.

Sedangkan solusi yang ditawarkan untuk mengatasi permasalahan yang dihadapi mitra (2) adalah membuat pakan lele sendiri dengan memanfaatkan kotoran puyuh yang dicampur dengan gereh/ tepung ikan.

\section{METODE}

Rencana Kegiatan dan Langkah-langkah Pelaksanaan pengabdian ini meliputi : (1) pemanfaatan limbah bulu ayam untuk ternak lele, (2) praktek pembuatan pelet menggunakan tepung bulu ayam dicampur bahan lain yang berupa usus ayam yang tidak termanfaatkan dan limbah lain yang tidak termanfaatkan yang bisa digunakan sebagai campuran pakan lele yang memiliki nilai gizi tinggi; dan (3) analisis kandungan protein pelet yang dihasilkan.

Partisipasi mitra dalam pelaksanakan program IbM ini meliputi: penyediaan bahan baku limbah bulu ayam, penyediaan tempat budidaya lele, dan penyediaan sumberdaya manusia sebagi subyek untuk dilatih berbagai kegiatan program ini.. 


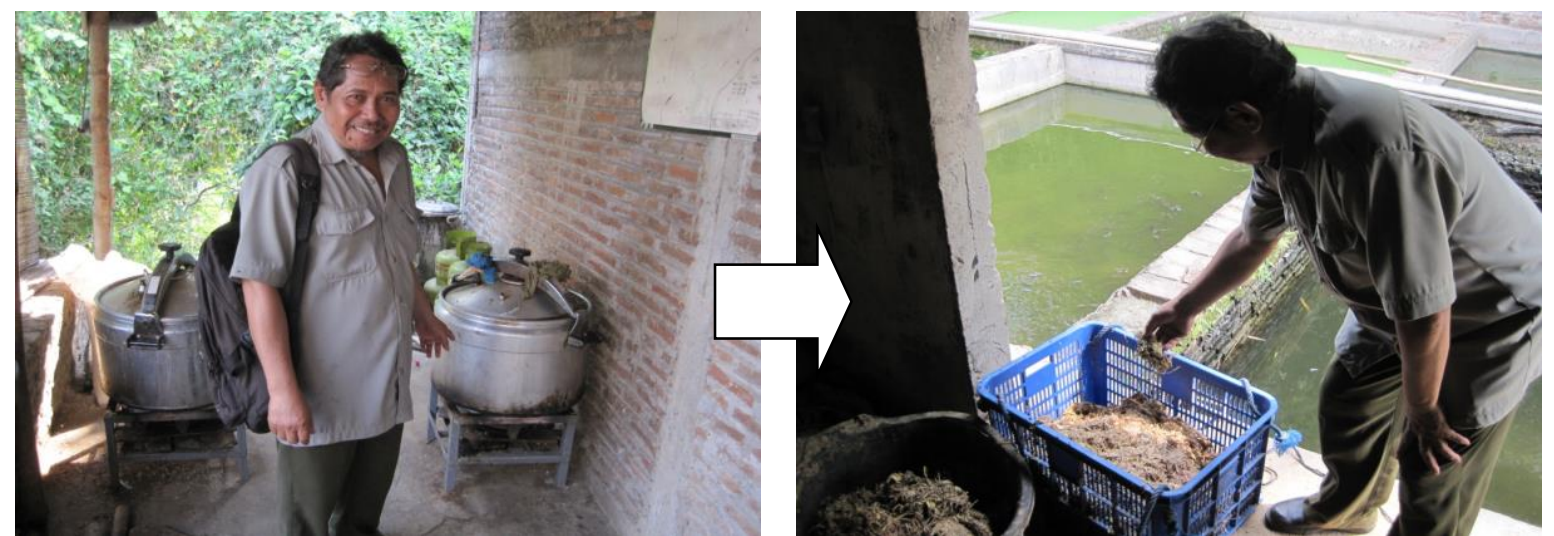

Bulu dimasak dengan alat masak bertekanan tinggi (Pressure cooker)

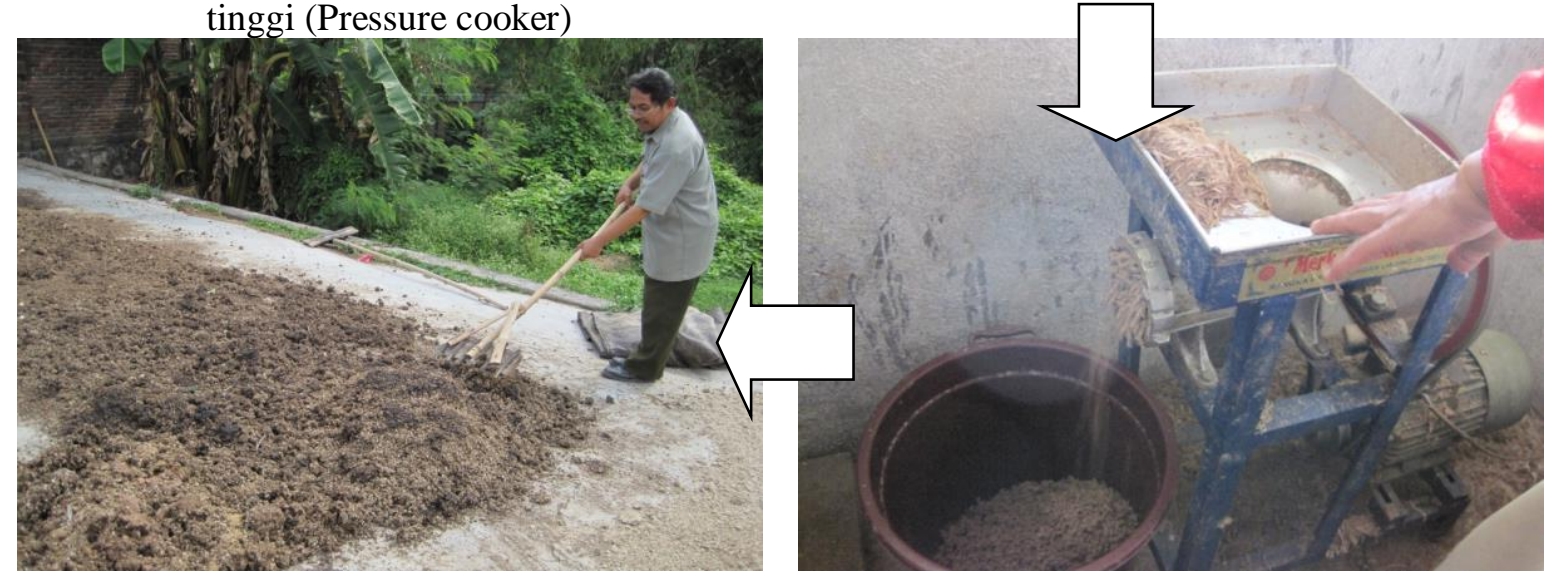

Bulu yang telah halus dijemur

Bulu yang telah matang (lunak) sedang dihaluskan

\section{HASIL DAN PEMBAHASAN}

Hasil yang dicapai dalam kegiatan pengabdian ini adalah :

1. Bantuan alat pencabut bulu ayam

2. Bantuan mesin pembuat pelet 1 unit dengan kapasitas $40 \mathrm{~kg} / \mathrm{jam}$

3. Bantuan kompor dan perlengkapannya

4. Bantuan alat masak bertekanan tinggi (Pressure cooker) 1 unit dengan kapasitas $70 \mathrm{~kg}$

5. Bantuan tepung ikan sebagai bahan pembuat pelet

6. Dilakukan praktek pembuatan pelet menggunakan limbah bulu ayam

7. Analisis protein hasil pembuatan pelet dari campuran limbah limbah bulu ayam. Analisa proksimat pelet dari campuran limbah limbah bulu ayam dilakukan sebanyak 3 kali ulangan

\section{KESIMPULAN}

1. Kegiatan pengabdian masyarakat di Pedagang Penyembelih Ayam 'Narti Ayam' merupakan usaha mikro milik Sunarti, di dukuh karangrejo, Desa Ngringo dan Peternakan Lele 'Berlian Catfish' merupakan usaha mikro milik Arfida Berliana di dukuh Gunung Sari, Desa Ngringo, Kec. Jaten, Kab. Karanganyar dengan cara memberikan bantuan teknologi tepat guna dan alat mesin dapat mengatasi limbah limbah bulu ayam untuk dijadikan pakan lele dengan harga murah.

2. Bantuan seperangkat alat mesin untuk pembuatan pakan lele dari bahan mentah sampai jadi pellet sangat membantu mengatasi limbah bulu ayam di Pedagang Penyembelih Ayam 'Narti Ayam' dan dapat mengatasi tingginya biaya produksi di Peternakan Lele 'Berlian Catfish'.

Tabel 1.Hasil analisis proksimat pelet dari campuran limbah limbah bulu ayam

\begin{tabular}{cccccc}
\hline Model & Protein $(\%)$ & Kadar Lemak $(\%)$ & $\begin{array}{c}\text { Serat Kasar } \\
(\%)\end{array}$ & $\begin{array}{c}\text { Kadar Abu } \\
(\%)\end{array}$ & Kadar Air $(\%)$ \\
\hline U1 & 35,57 & 8,26 & 16,05 & 13,33 & 7,23 \\
U2 & 35,04 & 8,36 & 14,32 & 12,59 & 7,62 \\
U3 & 35,08 & 8,56 & 15,42 & 11,36 & 7,87 \\
\hline
\end{tabular}




\section{UCAPAN TERIMA KASIH}

Ucapan terima kasih disampaikan kepada Dirjen Pendidikan Tinggi yang telah mendanai kegiatan ini melalui Dana Hibah Ipteks bagi Masyarakat Tahun Anggaran 2014. Ucapan terima kasih juha disampaikan kepada UKM Peternak Lele Berlian Fish dan Pedagang Penyembelihan Ayam Narti Ayam yang telah bersedia menjadi mitra dan mendukung kegiatan IbM ini.

\section{DAFTAR PUSTAKA}

Anonim. 2011. Budidaya Lele di Kolam Terpal. http://bp4kkabsukabumi.net/ index.php/Perikanan/BUDIDAYALELE-DI-KOLAM-TERPAL.html

Anonim. 2011. Manfaat Bulu Ayam sebagai Bahan Pakan http://duniaternakmodern. blogspot. com/2011/12/manfaat-bulu-ayamsebagai-bahan-pakan.html
Anonim. 2009. Tiap hari, 12 ton lele dikonsumsi. http://www.waspada.co.id/ index.php?option=com_content $\&$ view $=\mathrm{a}$ rticle\&id=35410:tiap-hari-12-ton-leledikonsumsi\&catid=95\&Itemid $=146$

Anggraeni, I. 2009. Efisiensi Serapan N dan Hasil Tanaman Padi (Oryza sativa L.) Pada Berbagai Imbangan Pupuk Kandang Puyuh dan Pupuk Anorganik Di Lahan Sawah Palur Sukoharjo (Musim Tanam II). Skripsi S1. Fak. Pertanian UNS. Surakarta.

Sitompul, Saulina. 2004. Analisis Asam Amino dalam Tepung Ikan dan Bungkil Kedelai. Buletin Teknik Pertanian Vol. 9 No. 1 tahun 2004. 